Check for updates

Cite this: RSC Adv., 2019, 9, 4140

\title{
Secondary metabolites from the endolichenic fungus Ophiosphaerella korrae $\uparrow$
}

\author{
Yue-Lan Li, ${ }^{a}$ Rong-Xiu Zhu, ${ }^{b}$ Gang Li, (DD ${ }^{c}$ Ning-Ning Wang, ${ }^{a}$ Chun-Yu Liu, ${ }^{a}$ \\ Zun-Tian Zhao ${ }^{d}$ and Hong-Xiang Lou (D) *a
}

The isolation of the cytotoxic fractions from the endolichenic fungus Ophiosphaerella korrae yielded six new metabolites, including five polyketides (ophiofuranones A (1) and B (2), with unusual furopyran-3,4dione-fused heterocyclic skeletons, ophiochromanone (3), ophiolactone (4), and ophioisocoumarin (5)), one sesquiterpenoid ophiokorrin (10), and nine known compounds. Their structures were established on the basis of the analysis of HRESIMS and NMR spectroscopic data. ECD calculations, GIAO NMR shift calculations and single-crystal $X$-ray diffraction were employed for the stereo-structure determination. A plausible biogenetic pathway for the ophiofuranones A (1) and B (2) was proposed. The cytotoxic assay suggested that the five known perylenequinones mainly contributed to the cytoxicity of the extract. Further phytotoxic studies indicated that ophiokorrin inhibited root elongation in the germination of Arabidopsis thaliana with an $\mathrm{IC}_{50}$ value of $18.06 \mu \mathrm{g} \mathrm{mL}^{-1}$.

Received 17th December 2018 Accepted 12th January 2019

DOI: 10.1039/c8ra10329a

rsc.li/rsc-advances gel column chromatography performed to find relevant biologically active components obtained twenty fractions (A-T). A previous chemical investigation on Fr. D and Fr. E with strong acetylcholinesterase inhibitory effects identified several rare secondary metabolites. ${ }^{9}$ Herein, we continued our chemical investigation on the three cytotoxic fractions G, I and L (which were active against the A549 cells with $\mathrm{IC}_{50}$ values of 13.36, 23.63 and $25.28 \mu \mathrm{g} \mathrm{mL} \mathrm{m}^{-1}$, respectively). Six new metabolites (1-5 and 10), together with nine known metabolites including four aromatic polyketides (6-9) and five perylenequinones (11-15), were obtained (Fig. 1). We found that the five known perylenequinones (11-15), as the major components, are responsible for the cytotoxic activity, as we have reported previously. ${ }^{\mathbf{1 0}}$ The details of the isolation, structure elucidation, plausible biogenetic pathway and phytotoxic activity of these compounds are reported here.

\section{Results and discussion}

Compound 1 was acquired as a white solid and has a molecular formula of $\mathrm{C}_{15} \mathrm{H}_{18} \mathrm{O}_{5}$ (requiring seven double bond equivalents, DBEs) as deduced from the pseudo-molecular-ion peak at $\mathrm{m} / \mathrm{z}$ 279.1229 $[\mathrm{M}+\mathrm{H}]^{+}$(calcd. 279.1227) in HRESIMS. The IR spectrum showed the characteristic absorption bands for the hydroxyl (3384 $\left.\mathrm{cm}^{-1}\right)$, carbonyl $\left(1747 \mathrm{~cm}^{-1}\right)$, olefinic (1607 $\left.\mathrm{cm}^{-1}\right)$ and terminal double bond $\left(911 \mathrm{~cm}^{-1}\right)$ functionalities. The ${ }^{1} \mathrm{H}$ NMR spectrum of 1 (Table 1) displayed the characteristic signals of a vinyl group $\left(-\mathrm{CH}=\mathrm{CH}_{2}\right)$ at $\delta_{\mathrm{H}} 6.41(\mathrm{dd}, J=$ 17.2, $\left.10.8 \mathrm{~Hz}, \mathrm{H}-3^{\prime}\right), 5.16$ (d, $\left.J=10.8 \mathrm{~Hz}, \mathrm{H}-4^{\prime} \mathrm{a}\right)$, and 5.35 (d, $J=$ $\left.17.2 \mathrm{~Hz}, \mathrm{H}-4^{\prime} \mathrm{b}\right)$, and suggested the presence of four methyl groups $\left(\delta_{\mathrm{H}} 1.32,1.36,1.56\right.$ and 1.82), one oxygenated methine 


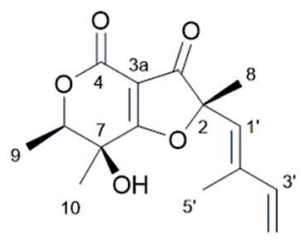

1

$2 \Delta^{1^{\prime}}=Z$

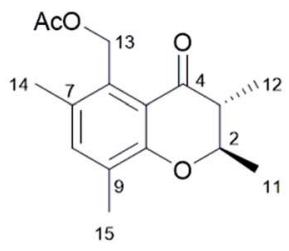

3<smiles>Cc1cc(C)c2c3c1O[C@H](C)[C@H](C)[C@H]3OC2=O</smiles>

4<smiles>[R]Oc1cc(O)c2c(c1[R])C([R2])(C)C(=[V])OC2=O</smiles>

$5 \mathrm{R}_{1}=\mathrm{R}_{2}=\mathrm{H}$

$6 \mathrm{R}_{1}=\mathrm{Me}, \mathrm{R}_{2}=\mathrm{OH}$<smiles>COc1cc(O)c2c(c1C)[C@H](C)[C@](O)(CO)OC2=O</smiles>

7<smiles>[R]CC(O)[C@]1(C)OC(=O)c2c(O)cc(OC)c(C)c21</smiles>

$8 \mathrm{R}=\mathrm{H}$<smiles>CC1=CC(=O)C[C@H](C)[C@]1(C)CC/C(C)=C/C(=O)O</smiles>

10

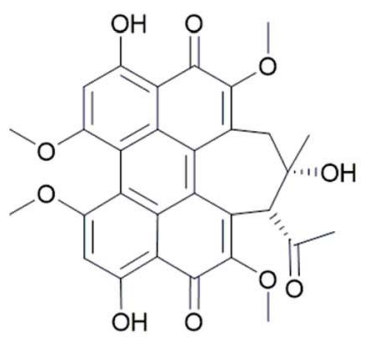<smiles></smiles>

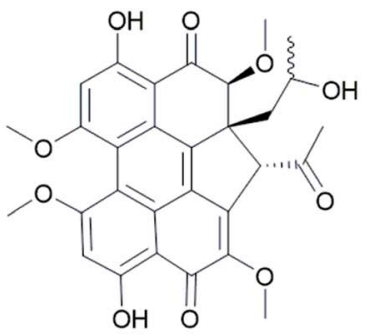

$12 \mathrm{R}_{1}=\mathrm{R}_{2}=\mathrm{Ac}$

11

$13 \mathrm{R}_{1}=\mathrm{CH}(\mathrm{OH}) \mathrm{Me}, \mathrm{R}_{2}=\mathrm{Ac}$

15

Fig. 1 Structures of the isolated compounds 1-15.

Table $1{ }^{1} \mathrm{H}$ and ${ }^{13} \mathrm{C}$ NMR data for compounds 1 and 2 in DMSO- $d_{6}$

\begin{tabular}{|c|c|c|c|c|}
\hline \multirow[t]{2}{*}{ Position } & \multicolumn{2}{|l|}{$\mathbf{1}^{a}$} & \multicolumn{2}{|l|}{$2^{b}$} \\
\hline & $\delta_{\mathrm{H}}$, mult. $(J$ in $\mathrm{Hz})$ & $\delta_{\mathrm{C}}$, type & $\delta_{\mathrm{H}}$, mult. $(J$ in $\mathrm{Hz})$ & $\delta_{\mathrm{C}}$, type \\
\hline 2 & & $93.2, \mathrm{C}$ & & $93.2, \mathrm{C}$ \\
\hline 3 & & 196.5, C & & 196.4, C \\
\hline 4 & & 159.0, C & & 159.1, C \\
\hline 6 & $4.61 \mathrm{q}(6.4)$ & $80.0, \mathrm{CH}$ & $4.62 \mathrm{q}(6.6)$ & $80.0, \mathrm{CH}$ \\
\hline 7 & & $66.8, \mathrm{C}$ & & $66.8, \mathrm{C}$ \\
\hline 9 & $1.32 \mathrm{~d}(6.4)$ & $12.8, \mathrm{CH}_{3}$ & $1.32 \mathrm{~d}(6.6)$ & $12.8, \mathrm{CH}_{3}$ \\
\hline 10 & $1.36 \mathrm{~s}$ & $18.4, \mathrm{CH}_{3}$ & $1.32 \mathrm{~s}$ & $18.5, \mathrm{CH}_{3}$ \\
\hline $1^{\prime}$ & $5.58 \mathrm{~s}$ & $126.4, \mathrm{CH}$ & $5.46 \mathrm{~s}$ & 124.1, CH \\
\hline $2^{\prime}$ & & $140.1, \mathrm{C}$ & & $133.3, \mathrm{C}$ \\
\hline $3^{\prime}$ & $6.41 \mathrm{dd}(17.2,10.8)$ & $140.2, \mathrm{CH}$ & $6.77 \mathrm{dd}(17.4,10.8)$ & $138.7, \mathrm{CH}$ \\
\hline $4^{\prime} \mathrm{a}$ & $5.16 \mathrm{~d}(10.8)$ & $115.5, \mathrm{CH}_{2}$ & $5.33 \mathrm{dt}(10.8,1.2)$ & $118.5, \mathrm{CH}_{2}$ \\
\hline
\end{tabular}

${ }^{a}{ }^{1} \mathrm{H}$ and ${ }^{13} \mathrm{C}$ NMR data recorded at 400 and $100 \mathrm{MHz} .{ }^{b}{ }^{1} \mathrm{H}$ and ${ }^{13} \mathrm{C}$ NMR data recorded at 600 and $150 \mathrm{MHz}$, respectively. 


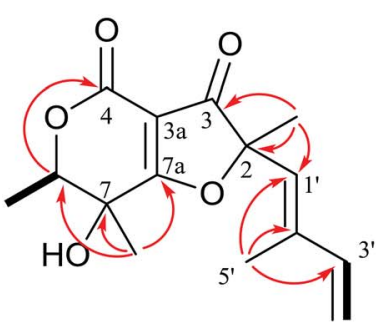

1

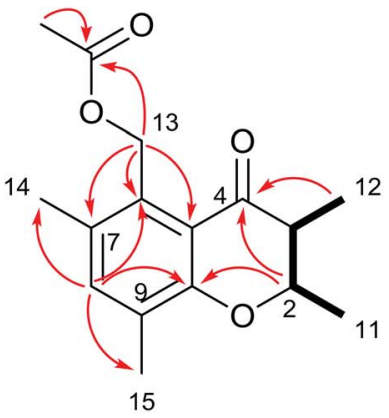

3

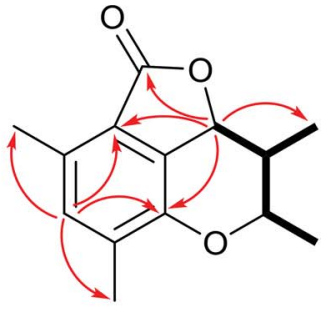

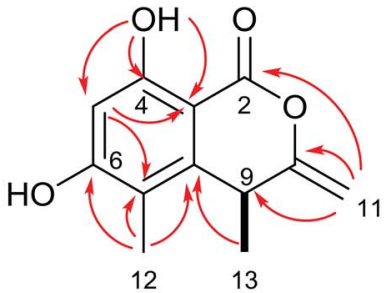

5

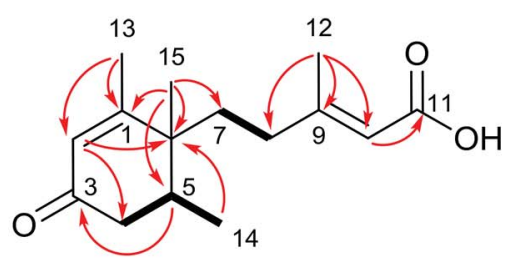

10

Fig. 2 Key $\mathrm{HMBC}$ (red arrows) and ${ }^{1} \mathrm{H}-{ }^{1} \mathrm{H}$ COSY (bold black lines) of 1, 3-5 and 10.

$\left(\delta_{\mathrm{H}} 4.61\right)$, one olefinic proton $\left(\delta_{\mathrm{H}} 5.58\right)$, and a hydroxyl group $\left(\delta_{\mathrm{H}}\right.$ 6.40). The ${ }^{13} \mathrm{C}$ NMR spectrum (Table 1 ) resolved fifteen carbon signals, which were assigned by the HSQC spectrum as four methyls, one methylene, three methines and seven quaternary carbons. With the aid of the ${ }^{1} \mathrm{H}-{ }^{1} \mathrm{H}$ COSY spectrum, two coupling systems were identified as $\mathrm{CH}\left(3^{\prime}\right)-\mathrm{CH}_{2}\left(4^{\prime}\right)$ and $\mathrm{CH}(6)-$ $\mathrm{CH}_{3}$ (9) (Fig. 2). The 2-methylbutadiene chain was established according to the key HMBC correlations from $\mathrm{H}_{3}-8$ to $\mathrm{C}-\mathbf{1}^{\prime}, \mathrm{C}-2$, and $\mathrm{C}-3\left(\delta_{\mathrm{C}} 196.5\right)$ and from $\mathrm{H}_{3}-5^{\prime}$ to $\mathrm{C}-1^{\prime}, \mathrm{C}-2^{\prime}$, and $\mathrm{C}-3$ ' (Fig. 2). The key HMBC correlations of $\mathrm{H}-6 / \mathrm{C}-4$ and of $\mathrm{H}_{3}-10 / \mathrm{C}-6, \mathrm{C}-7$, and $\mathrm{C}-7 \mathrm{a}\left(\delta_{\mathrm{C}}\right.$ 195.2), together with three residual quaternary carbons $\left(\delta_{\mathrm{C}} 102.1,159.0\right.$, and 195.2) with the characteristic chemical shifts for an $\alpha, \beta$-unsaturated ester/acid, ${ }^{11}$ indicated a $\alpha$-pyrone moiety (Fig. 2). Given the downfield chemical shifts and molecular formula, the olefinic carbon C-7a forms an ether bond with C-2 $\left(\delta_{\mathrm{C}} 93.2\right)$ to fulfill the DBEs. Finally, the planar

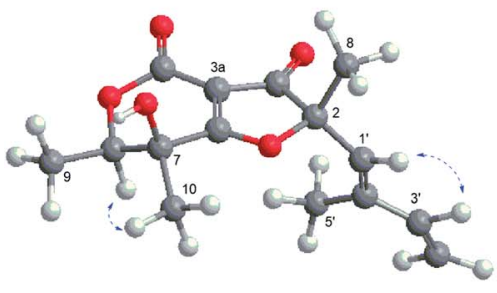

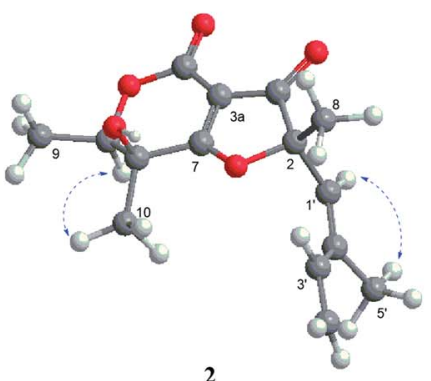

2

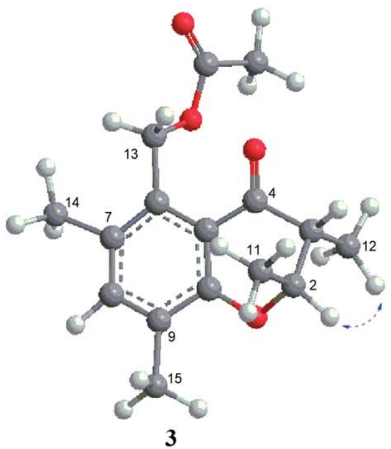

3
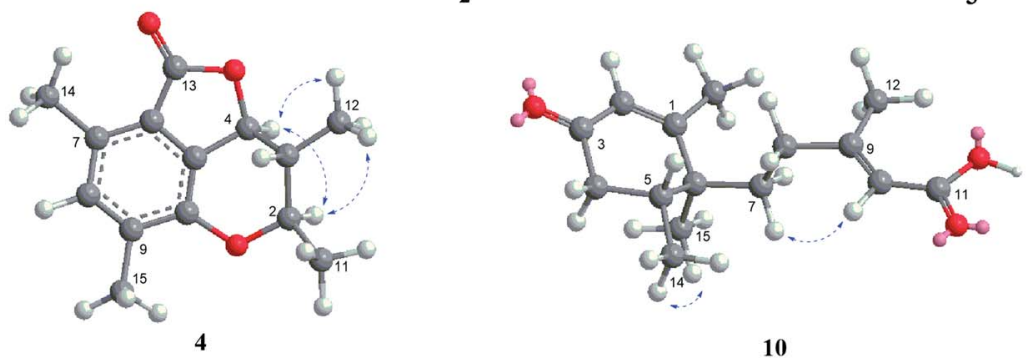

10

Fig. 3 Key NOESY (dash arrows) correlations of 1-4 and 10. 
A

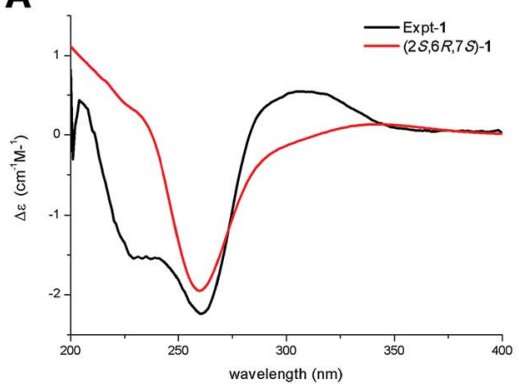

B

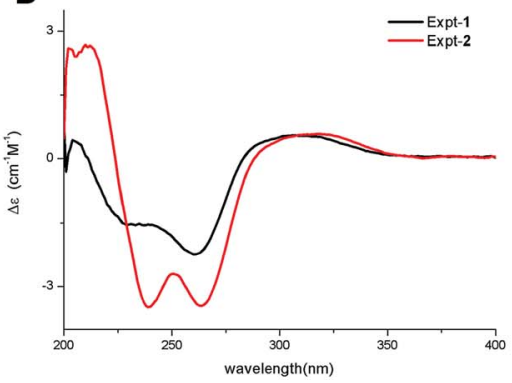

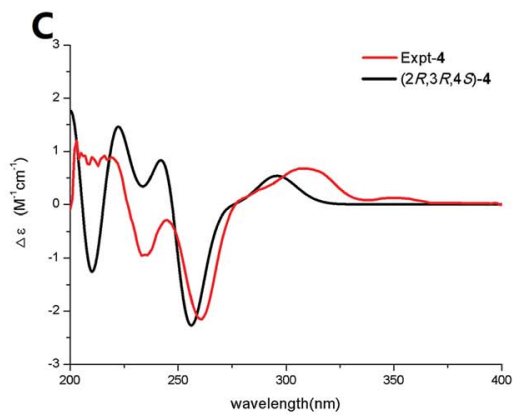

Fig. 4 Experimental and calculated ECD spectra of 1 (A), 2 (B) and 4 (C).

Table $2{ }^{1} \mathrm{H}$ and ${ }^{13} \mathrm{C}$ NMR data for compounds 3 and 4 in DMSO- $d_{6}$

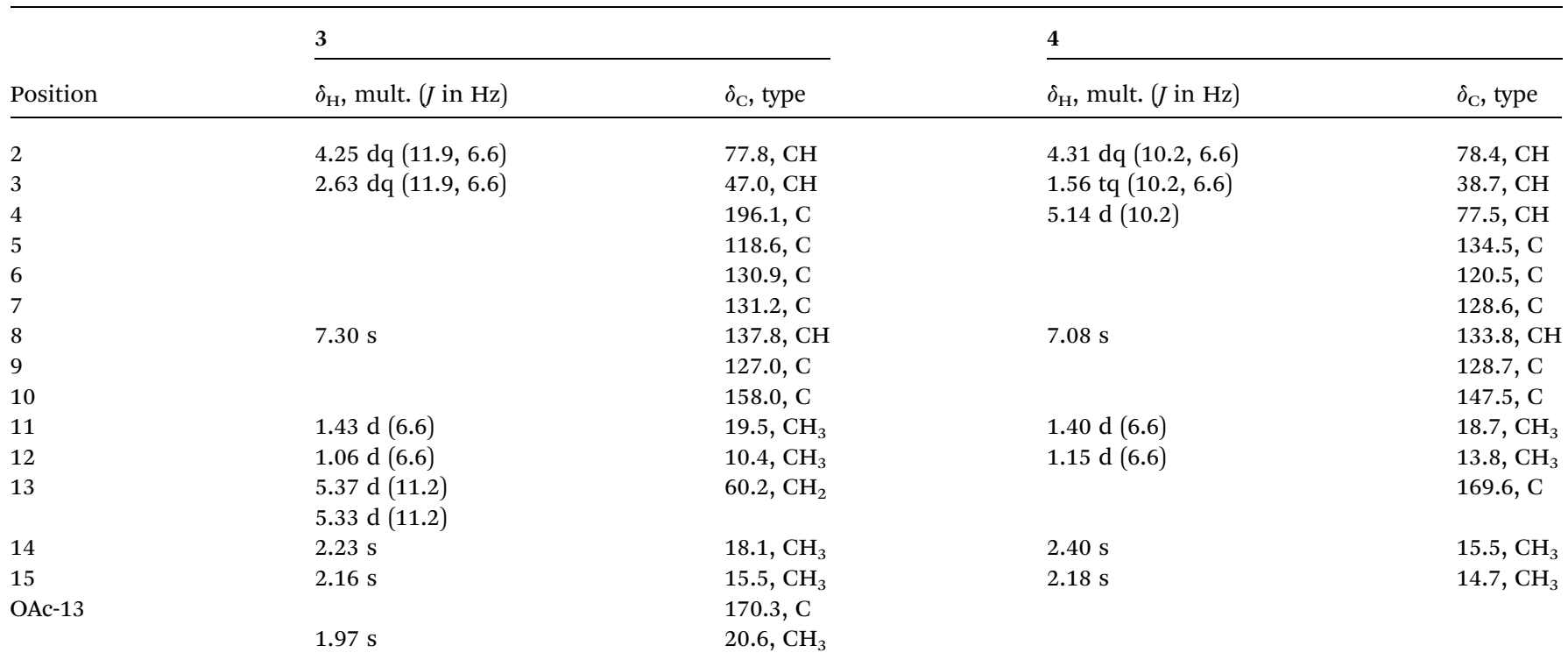

${ }^{a} \mathrm{H}$ and ${ }^{13} \mathrm{C}$ NMR data recorded at 600 and $150 \mathrm{MHz}$.

structure of 1 was elucidated as a furopyran-3,4-dione-fused heterocyclic core linked with a 2-methylbutadiene side chain. The furopyran-3,4-dione-fused heterocyclic core is unusual in natural products and was further confirmed by comparative analysis of its chemical shift values with those in the known cyclogregatin, which was first isolated from Aspergillus panamensis $^{\mathbf{1 2}}$ in 1988 by Anke et al. and revised as a type-c furancarboxylic acid derivative by Burghar-Stoll and Brückner in $2012 .{ }^{13}$ The configuration of the double bond at $\mathrm{C}^{\prime}=\mathrm{C} 2^{\prime}$ was assigned to be $E$ on the basis of the NOESY correlation of $\mathrm{H}-\mathrm{1}^{\prime}$ and $\mathrm{H}-3$ ' (Fig. 3).

In the NOESY spectrum, the cross-peak of $\mathrm{H}-6 / \mathrm{H}_{3}-10$ suggested that they were cofacial (Fig. 3). However, the NOESY correlation failed to assign the location of $\mathrm{H}_{3}-8$ relative to $\mathrm{H}_{3}-10$ and $\mathrm{H}-6$. Therefore, ECD calculations for four configurations $(2 S, 6 R, 7 S ; 2 R, 6 R, 7 S ; 2 S, 6 S, 7 R ;$ and $2 R, 6 S, 7 R)$ of compound 1 were directly applied to confirm the absolute configuration of $\mathbf{1}$ (Fig. 4A and S60 $\dagger$ ). ECD calculations were performed on the B3PW91/TZVP//mPW1PW91/6-311G(d) level of theory. The result showed that the experimental ECD absorption band of 1 had better accuracy with the calculated ECD absorption band of
$(2 S, 6 R, 7 S)-1$ (Fig. 4A), which was also supported by the GIAO NMR shift calculation at the mPW1PW91/6-31+G(d,p)//B3LYP/ 6-31G(d) level of theory ${ }^{\mathbf{1 4 , 1 5}}$ (Table S1 and Fig. S64 $\dagger$ ). As a result, 1 was finally determined as $(2 S, 6 R, 7 S)$-7-hydroxy-2,6,7trimethyl-2-((E)-2-methylbuta-1,3-dien-1-yl)-6,7-dihydro- $4 H$-furo $[3,2-c]$ pyran-3,4 $(2 H)$-dione and named ophiofuranone A.

Compound 2 was simultaneously obtained with 1 using RPHPLC $\left(47 \% \mathrm{MeOH}\right.$ in $\left.\mathrm{H}_{2} \mathrm{O}\right)$ and had a very similar NMR profile to 1 . The main difference was observed in the geometric configuration of the $\mathrm{C}-1^{\prime}=\mathrm{C}-2^{\prime}$ double bond. Compound 2 was determined as $\Delta^{1^{\prime}\left(2^{\prime}\right)} Z$ due to the NOESY correlation between $\mathrm{H}$ $1^{\prime}\left(\delta_{\mathrm{H}} 5.46\right)$ and $\mathrm{H}_{3}-5^{\prime}\left(\delta_{\mathrm{H}} 1.85\right)$ (Fig. 3). The identical NMR data with those of 1 suggested the same relative configuration as $\mathbf{1}$ in the furopyran-3,4-dione-fused heterocyclic core (Table 1). Moreover, the experimental ECD curve highly matched that of 1 (Fig. 4B), implying the same absolute configurations of the three asymmetric carbons. Thus, 2 was determined as $(2 S, 6 R, 7 S)$-7-hydroxy-2,6,7-trimethyl-2-((Z)-2-methylbuta-1,3dien-1-yl)-6,7-dihydro-4H-furo[3,2-c]pyran-3,4(2H)-dione and named ophiofuranone $\mathrm{B}$. 


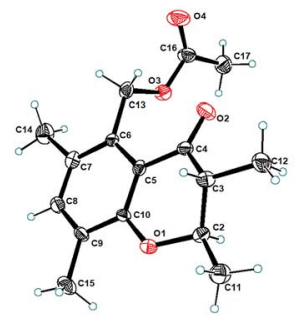

3

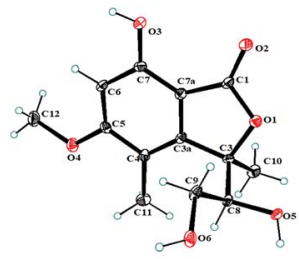

9

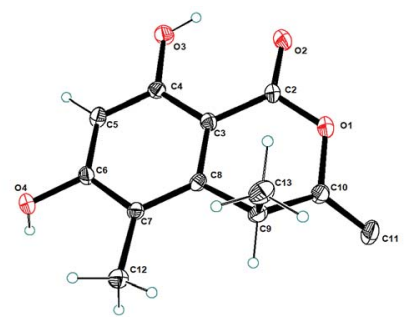

5

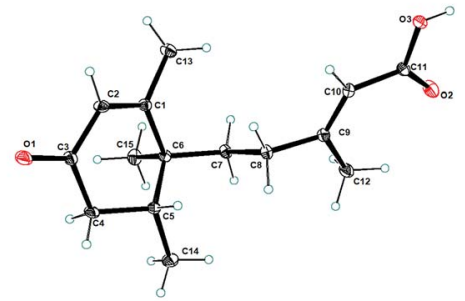

10
Fig. 5 The X-ray crystallographic structures of 3, 5, 9 and 10 .

Compound 3 was in the form of white needles and displayed a molecular formula of $\mathrm{C}_{16} \mathrm{H}_{20} \mathrm{O}_{4}$, as determined by HRESIMS ( $\mathrm{m} / \mathrm{z} 299.1261[\mathrm{M}+\mathrm{H}]^{+}$, calcd. 299.1259), indicating seven DBEs. The IR spectrum showed absorption bands for ester carbonyl (1727 $\mathrm{cm}^{-1}$ ) and benzoyl (1684, 1603, and $1582 \mathrm{~cm}^{-1}$ ) functionalities. Analysis of the 1D NMR data of 3 (Table 2) revealed five methyls, one methylene, two methines (one oxygenated), six aromatic carbons (proved to be a pentasubstituted phenyl), one ketone carbonyl and one ester carbonyl. The presence of a pentasubstituted aromatic ring was supported by the HMBC correlations from $\mathrm{H}-8\left(\delta_{\mathrm{H}} 7.30\right)$ to $\mathrm{C}-6, \mathrm{C}-10, \mathrm{C}-14$, and $\mathrm{C}-15$ and from $\mathrm{H}_{2}-13\left(\delta_{\mathrm{H}} 5.37,5.33\right)$ to $\mathrm{C}-5$, C-6, and C-7 (Fig. 2). The ${ }^{1} \mathrm{H}-{ }^{1} \mathrm{H}$ COSY data of 3 revealed the presence of the spin- coupling system $\mathrm{CH}_{3}(11)-\mathrm{CH}(2)-\mathrm{CH}(3)-\mathrm{CH}_{3}(12)$ shown by bold black lines in Fig. 2. The aforementioned fragments were assembled into a chromanone core using the HMBC correlations from $\mathrm{H}_{3}-12\left(\delta_{\mathrm{H}} 1.06\right)$ to $\mathrm{C}-4$ and from $\mathrm{H}-2\left(\delta_{\mathrm{H}} 4.25\right)$ to $\mathrm{C}-4$ and C-10 (Fig. 2). The large coupling constant $J_{\mathrm{H}_{2}-\mathrm{H}_{3}}(11.9 \mathrm{~Hz})$ observed in the ${ }^{1} \mathrm{H}$ NMR spectrum of 3 reflected the transorientation for $\mathrm{H}-2 / \mathrm{H}-3$, which was also confirmed by the NOESY correlation of $\mathrm{H}-2 / \mathrm{H}_{3}-12$ and $\mathrm{H}-3 / \mathrm{H}_{3}-11$ (Fig. 3). A positive $\mathrm{n} \rightarrow \pi^{*} \mathrm{CE}$ at $351 \mathrm{~nm}(\Delta \varepsilon=+0.83)$ indicated a $2 R$ configuration by analysis of the ECD spectrum (Fig. S29 $\dagger$ ). ${ }^{\mathbf{1 6 , 1 7}}$ Moreover, the stereochemistry of $\mathbf{3}$ was further confirmed as $2 R, 3 R$ by single-crystal X-ray diffraction analysis (CCDC 1855706) (Fig. 5), and 3 was named ophiochromanone.

Compound 4 was deduced to have the molecular formula $\mathrm{C}_{14} \mathrm{H}_{16} \mathrm{O}_{3}$ from HRESIMS, indicating seven DBEs. The main difference of the ${ }^{13} \mathrm{C}$ NMR spectra between 3 and 4 was the presence of an ester signal $\left(\delta_{\mathrm{C}} 169.6, \mathrm{C}-13\right)$ and an oxygenated methine $\left(\delta_{\mathrm{C}} 77.5, \mathrm{C}-4\right)$ instead of the methylene and keto carbonyl groups in 3 with the absence of an acetoxy signal. On the basis of the ${ }^{1} \mathrm{H}-{ }^{1} \mathrm{H}$ COSY and HMBC correlations (Fig. 2), the planar structure of $\mathbf{4}$ was established to fulfil the DBEs. The presence of the $\mathrm{H}-2 / \mathrm{H}_{3}-12 / \mathrm{H}-4$ NOESY correlations (Fig. 3) determined the same side orientation of $\mathrm{H}-2, \mathrm{H}_{3}-12$ and $\mathrm{H}-4$, which was also supported by the large coupling constants of $J_{\mathrm{H}_{2}-\mathrm{H}_{3}}$ and $J_{\mathrm{H}_{3}-\mathrm{H}_{4}}(10.2$ and $10.2 \mathrm{~Hz}$, respectively). The experimental ECD spectrum of $\mathbf{4}$ was consistent with the calculated ECD curve of $(2 R, 3 R, 4 S)-4$ (Fig. $4 \mathrm{C})$. Ultimately, the structure of 4 was established as shown in Fig. 1 and 4 was named ophiolactone.

Compound 5 was obtained as white needles from $\mathrm{MeOH}$, with the molecular formula of $\mathrm{C}_{12} \mathrm{H}_{12} \mathrm{O}_{4}$ by HRESIMS. The 1D and 2D NMR spectra (Table 3 and Fig. 2) of 5 closely resembled those of $(S)$-8-hydroxy-6-methoxy-4,5-dimethyl-3-methylene-isochromen-1-one, ${ }^{\mathbf{1 8 , 1 9}}$ except that a hydroxyl is in the place of

Table $3{ }^{1} \mathrm{H}$ and ${ }^{13} \mathrm{C}$ NMR data for compounds 5 and 10

\begin{tabular}{|c|c|c|c|c|}
\hline \multirow[b]{2}{*}{ Position } & \multicolumn{2}{|l|}{$5^{a}$} & \multicolumn{2}{|l|}{$10^{b}$} \\
\hline & $\delta_{\mathrm{H}}$, mult. $(J$ in $\mathrm{Hz})$ & $\delta_{\mathrm{C}}$, type & $\delta_{\mathrm{H}}$, mult. $(J$ in $\mathrm{Hz})$ & $\delta_{\mathrm{C}}$, type \\
\hline 2 & & 167.6, C & $5.78 \mathrm{~s}$ & 127.7, CH \\
\hline 3 & & $98.8, \mathrm{C}$ & & 197.4, C \\
\hline 4 & & 163.3, C & $2.22 \mathrm{~m}$ & 41.6, $\mathrm{CH}_{2}$ \\
\hline 7 & & 113.8, C & $1.65 \mathrm{~m}$ & $33.7, \mathrm{CH}_{2}$ \\
\hline 8 & & $144.3, \mathrm{C}$ & $2.13 \mathrm{~m}, 1.76 \mathrm{~m}$ & $34.8, \mathrm{CH}_{2}$ \\
\hline 9 & $4.06 \mathrm{q}(7.2)$ & $35.3, \mathrm{CH}$ & & $158.7, \mathrm{C}$ \\
\hline 10 & & 158.6, C & $5.63 \mathrm{~s}$ & $116.0, \mathrm{CH}$ \\
\hline 11 & $4.71,4.72($ each br s) & $95.8, \mathrm{CH}_{2}$ & $11.89 \mathrm{~s}$ & $167.4, \mathrm{COOH}$ \\
\hline 12 & $2.11 \mathrm{~s}$ & $10.0, \mathrm{CH}_{3}$ & $2.09 \mathrm{~s}$ & $18.3, \mathrm{CH}_{3}$ \\
\hline
\end{tabular}

${ }^{a}{ }^{1} \mathrm{H}$ and ${ }^{13} \mathrm{C}$ NMR data recorded at 600 and $150 \mathrm{MHz}$ in acetone- $d_{6} \cdot{ }^{b}{ }^{1} \mathrm{H}$ and ${ }^{13} \mathrm{C}$ NMR data recorded at 400 and $100 \mathrm{MHz}$ in DMSO- $d_{6}$, respectively. 


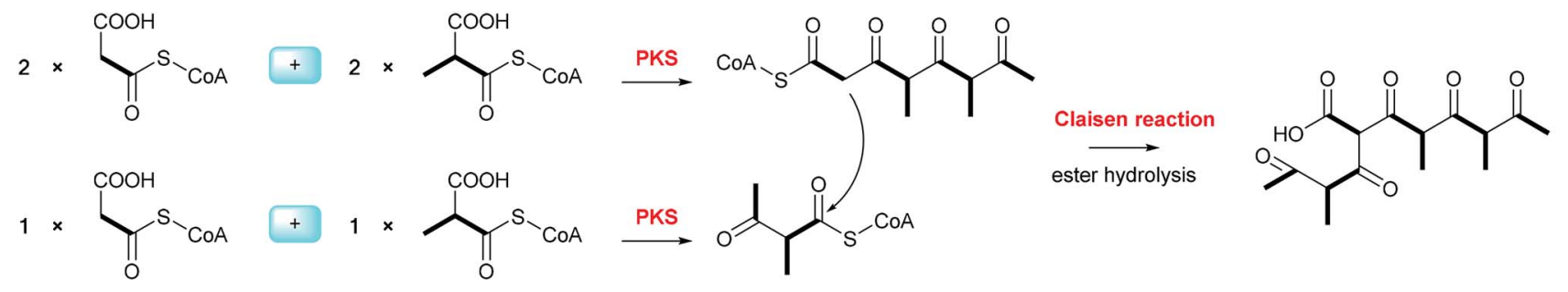<smiles>CC(=O)C(C)C(=O)C(C)C(=O)C(C(=O)O)=C(O)C(C)C(C)=O</smiles><smiles>CC(=O)C(C)C(=O)C1(C)OC(C(C)(O)C(C)=O)=C(C(=O)O)C1=O</smiles>
[H]<smiles>C=C/C(C)=C/C1(C)OC2=C(C(=O)OC(C)C2(C)O)C1=O</smiles><smiles>C=C/C(C)=C\C1(C)OC2=C(C(=O)OC(C)C2(C)O)C1=O</smiles>

Scheme 1 A proposed biogenetic pathway for compounds 1 and 2 .

a methoxyl at C-6 $\left(\delta_{\mathrm{C}} 164.4\right)$. The absolute configuration of 5 was determined as $9 S$ by the uniform ECD CEs $[240 \mathrm{~nm}(\Delta \varepsilon=$ +10.15), 271 (+11.8), $315(-1.72)]$ with $(S)$-8-hydroxy-6-methoxy4,5-dimethyl-3-methylene-isochromen-1-one. The single-crystal $\mathrm{X}$-ray diffraction using $\mathrm{Cu} \mathrm{K} \alpha$ radiation confirmed the assignment of the $9 S$ absolute configuration for 5 (Fig. 5, CCDC 1849055), and this compound was named ophioisocoumarin.
Compound 10 had a molecular formula of $\mathrm{C}_{15} \mathrm{H}_{22} \mathrm{O}_{3}$ by HRESIMS. The ${ }^{13} \mathrm{C}$ NMR results (Table 3) along with the HSQC data of $\mathbf{1 0}$ confirmed the presence of four methyls, three methylenes, one $\mathrm{sp}^{3}$ methine, one quaternary $\mathrm{sp}^{3}$ carbon, one keto carbonyl, one carboxyl and four olefinic carbons. An $\alpha, \beta$ unsaturated cyclohexenone ring was elucidated by the HMBC correlations from $\mathrm{H}_{3}-15$ to $\mathrm{C}-1$, C-5, and C-6, from $\mathrm{H}_{3}-13$ to C-1,
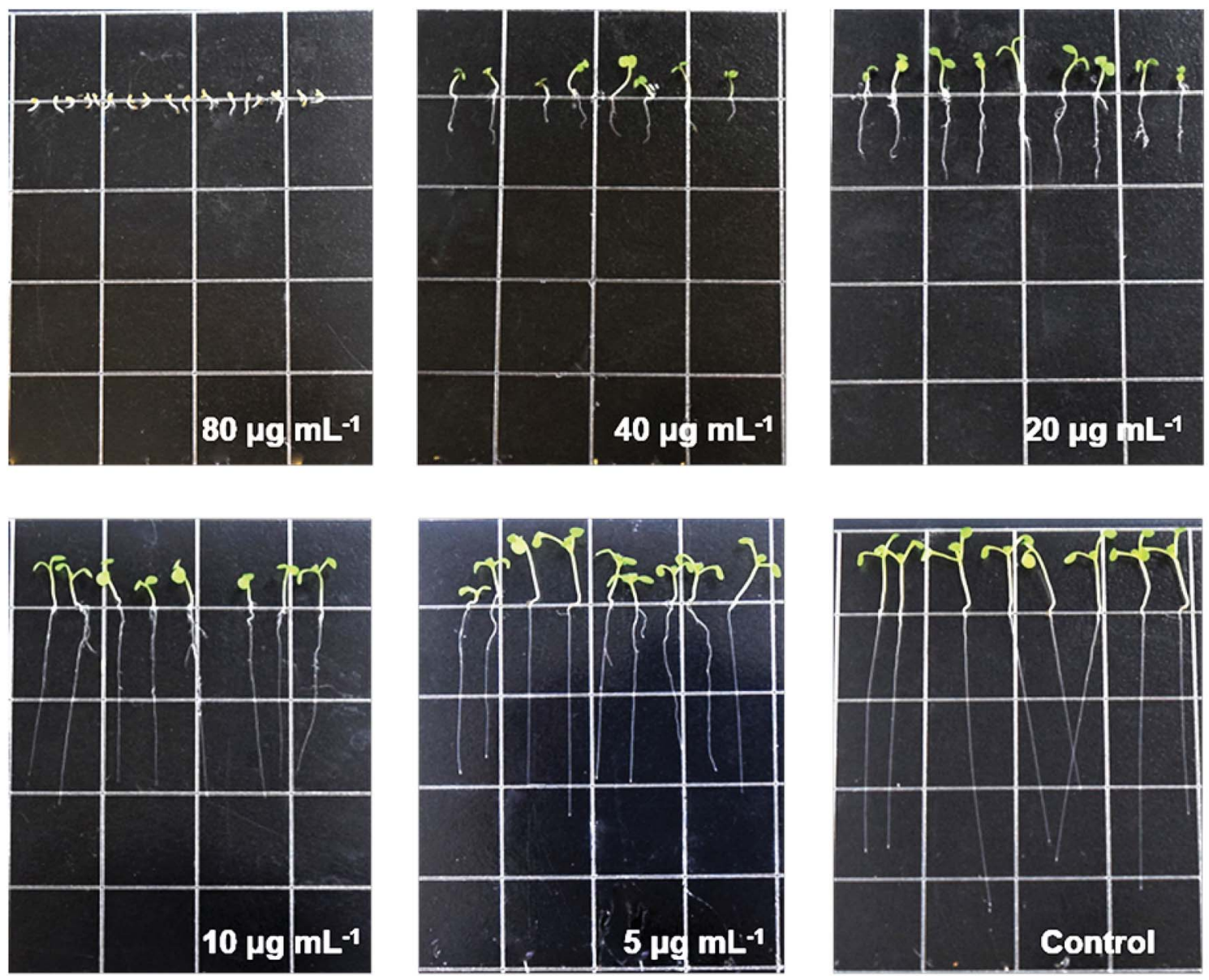

Fig. 6 The root elongation of $A$. thaliana on Petri dishes with different doses of compound 10. 
from $\mathrm{H}-2$ to $\mathrm{C}-4$ and $\mathrm{C}-6$ and from $\mathrm{H}-5$ to $\mathrm{C}-3$ together with the proton spin system $\mathrm{CH}_{2}(4)-\mathrm{CH}(5)-\mathrm{CH}_{3}(14)$ indicated by the ${ }^{1} \mathrm{H}-{ }^{1} \mathrm{H}$ COSY correlations (Fig. 2). Another spin system of $\mathrm{CH}_{2}(7)-\mathrm{CH}_{2}$ (8) together with the HMBC correlations of $\mathrm{H}_{3}-12 / \mathrm{C}$ 8, C-9, C-10 and H-10/C-11 confirmed a branched chain of carboxylic acid. The branched chain was attached to the $\alpha, \beta$ unsaturated cyclohexenone ring, which was supported by the key HMBC correlation from $\mathrm{H}_{3}-15$ to C-7. The NOESY correlations of $\mathrm{H}_{2}-8 / \mathrm{H}-10$ determined the $\Delta^{9}$ double bond as $E$ (Fig. 3 ). Moreover, $\mathrm{H}_{3}-14$ and $\mathrm{H}_{3}-15$ were assigned to be the same side orientation by the NOESY correlation of $\mathrm{H}_{3}-14 / \mathrm{H}_{3}-15$ (Fig. 3). According to the X-ray diffraction data (Fig. 5, CCDC 1855023), the absolute configuration of $\mathbf{1 0}$ was assigned as $5 R, 6 S$, and compound 10 was named ophiokorrin.

Compound 9 was isolated as massive colourless crystals. The NMR profiles of $\mathbf{9}$ were exactly consistent with those of the known compound clearanol $\mathrm{E}^{20}$ which was first isolated as a $1: 1$ mixture with clearanol D from two of the fungal isolates [a glomeromycete (possibly Entrophospora sp.) and a dothideomycete (possibly Phaeosphaeria sp.)]. The relative configuration of the C3-C8 segment was established as anti by single-crystal X-ray diffraction (Fig. 5 CCDC 1873977). According to the coincident ECD data with those of the calculated $(3 R, 8 S)-\mathbf{9}$, the absolute structure was assigned. Here, the stereochemistry of clearanol $\mathrm{E}$ is determined for the first time $\left[\mathrm{mp} 80-85{ }^{\circ} \mathrm{C} ;[\alpha]_{20}^{\mathrm{D}}=-26.6(c \quad 0.1, \mathrm{MeOH})\right]$. The other known compounds were identified as (R)-3,4-dihydro-4,8-dihydroxy-6methoxy-4,5-dimethyl-3-methyleneisochromen-1-one $(\mathbf{6}){ }^{21}(3 R, 8 S)$ dihydroxy-3-hydroxymethyl-6-methoxy-4,5-dimethylisochroman-1-

one $(7),{ }^{21} \quad(R)-7$-hydroxy-3-((S)-1-hydroxyethyl)-5-methoxy-3,4-dimethylisobenzofuran-1(3H)-one (8), ${ }^{22}$ hypocrellins A (11), elsinochromes A-C (12-14) and phaeosphaerin C $(\mathbf{1 5})^{\mathbf{1 0}}$ by comparison of their spectroscopic data with those reported.

Ophiofuranones A (1) and B (2) are rare furopyran-3,4-dionefused heterocyclic polyketides. Taking the unique structure features into consideration, a polyketide biosynthetic pathway was proposed (Scheme 1). Originating from propionate and acetate units, the polyketide chain was connected ultimately through a Claisen reaction. ${ }^{\mathbf{2 3 2 4}}$ After a sequence of post-PKS modifications, compounds $\mathbf{1}$ and $\mathbf{2}$ were biosynthesized separately.

Given the amounts and structure features of 1-15, five compounds (6-8, 10 and 13) were tested with models of $A$. thaliana (thale cress, Brassicaceae) root elongation. Only compound 10, as an analogue of the well-known phytohormone abscisic acid, ${ }^{25,26}$ showed an inhibitory activity on the root elongation in the germination of $A$. thaliana (Fig. 6) with an $\mathrm{IC}_{50}$ value of $18.06 \mu \mathrm{g} \mathrm{mL}{ }^{-1}$ (Fig. 6 and $\mathrm{S} 65 \dagger$ ).

\section{Conclusions}

In summary, six new metabolites (1-5 and 10) and nine known compounds (6-9 and 11-15) were isolated and identified from the EtOAc extract of O. korrae. Ophiofuranones A (1) and B (2), possessing an unusual furopyran-3,4-dione-fused heterocyclic skeleton, were assumed to be derived from the PKS pathway. Ophiokorrin (10), as an analogue of the well-known phytohormone abscisic acid, could inhibit root elongation in the germination of $A$. thaliana according to the results of the phytotoxic assay.

\section{Experimental section}

\section{General experimental procedures}

All NMR spectra were acquired on a Bruker AVIII 400 spectrometer $\left({ }^{1} \mathrm{H}: 400 \mathrm{MHz},{ }^{13} \mathrm{C}: 100 \mathrm{MHz}\right)$ or a Bruker Avance DRX600 spectrometer $\left({ }^{1} \mathrm{H}: 600 \mathrm{MHz},{ }^{13} \mathrm{C}: 150 \mathrm{MHz}\right)$ using TMS as the internal standard. HRESIMS data were obtained using a Thermo Scientific LTQ-Orbitrap XL. UV and CD spectra were obtained from a Chirascan spectropolarimeter. IR spectra were recorded on a Nicolet NEXUS 470 FT-IR (Thermo Fisher Scientific, Inc., Hudson, NH, USA) using $\mathrm{KBr}$ discs. Optical rotations were provided on an MCP 200 polarimeter from Anton Paar. Melting points (uncorrected) were observed on an X-6 meltingpoint apparatus (Beijing TECH Instrument Co. Ltd.). Medium Pressure Liquid Chromatography (MPLC) was carried out on a Lisure EZ Purifier apparatus equipped with a dual-wavelength UV-Vis detector (Lisure Science (Suzhou) Co., ltd.) and an ODS column (column size: $30 \times 130 \mathrm{~mm}$ ). Semipreparative HPLC was accomplished on an Agilent 1100 series instrument with Eclipse $\mathrm{XDB}^{-\mathrm{C}_{18}} 5 \mu \mathrm{m}$ columns (column size: $9.4 \times 250 \mathrm{~mm}$ ). Silica gel (200-300 mesh; Marine Chemical Ltd., Qingdao, China), Sephadex LH-20 (Pharmacia Biotek, Denmark), and reversed phase $\mathrm{C}_{18}$ silica gel (150-200 mesh, Merck) were used for column chromatography. Pre-coated silica gel GF254 plates (Marine Chemical Ltd., Qingdao, China) were used for TLC. Spots of TLC were visualized under UV light $(254 \mathrm{~nm})$ or by spraying with $\mathrm{H}_{2} \mathrm{SO}_{4} / \mathrm{EtOH}(1: 9$, v/v), followed by heating. 1/2 MS medium was purchased from Qingdao Hope BioTechnology Co., Ltd.

\section{Strain and fermentation}

The fungus $O$. korrae was isolated from the lichen Physciaceae physcia which was collected in Ditch Muzhate, Zhaosu, Xinjiang, China (coordinates of $80^{\circ} 08^{\prime}-81^{\circ} 30^{\prime} \mathrm{E}, 43^{\circ} 09^{\prime}-43^{\circ} 15^{\prime} \mathrm{N}$ ). The strain, assigned no. $0207 \mathrm{~b}$, was identified by the nuclear 18S rDNA sequences (GenBank: KC841077). The voucher strain was deposited in the Key Lab of Chemical Biology of Ministry of Education, Shandong University. O. korrae was cultured on PDA plates at $25{ }^{\circ} \mathrm{C}$ for 7 days. Mycelium was inoculated into three $300 \mathrm{~mL}$ Erlenmeyer flasks containing $100 \mathrm{~mL}$ of PDB medium and cultured at $25{ }^{\circ} \mathrm{C}$ for 10 days on a rotary shaker $(110 \mathrm{rpm})$. The fungus $O$. korrae was grown on a solid sterile rice medium $(20 \times 500 \mathrm{~mL}$ Fernbach culture flasks, each containing $80 \mathrm{~g}$ of rice and $120 \mathrm{~mL}$ of distilled water) for 40 days at room temperature.

\section{Extraction and isolation}

The fermented rice substrate was extracted repeatedly with EtOAc $(3 \times 10 \mathrm{~L})$ and $44 \mathrm{~g}$ of crude extract was obtained by evaporating the solvent under vacuum. The crude extract (44 g) was partitioned between water and EtOAc $(1: 2)$ three times. The EtOAc extract was separated into 20 fractions (A-T) by silica 
gel $\mathrm{CC}$, eluted with a step gradient of $\mathrm{CH}_{2} \mathrm{Cl}_{2}-\mathrm{MeOH}$ from $100: 0$ to $0: 100(\mathrm{v} / \mathrm{v})$.

Fr. G (1.16 g) was separated by Sephadex LH-20 CC twice, eluted with $\mathrm{CH}_{2} \mathrm{Cl}_{2}-\mathrm{MeOH}(1: 1)$ and $\mathrm{MeOH}$ successively. Fr. G2 (0.49 g) was divided into 7 parts $(\mathrm{a}-\mathrm{g})$ by MPLC. Fr. G2c (105.8 mg) was purified by semipreparative reversed-phase (RP) HPLC using 70\% $\mathrm{MeOH}-\mathrm{H}_{2} \mathrm{O}$ (flow rate: $1.5 \mathrm{~mL} \mathrm{~min}^{-1}$ ) as the solvent system, to afford $5\left(5.1 \mathrm{mg}, t_{\mathrm{R}}=26.4 \mathrm{~min}\right)$ and 4 (1.4 mg, $\left.t_{\mathrm{R}}=38.5 \mathrm{~min}\right)$. Under the same purifying conditions, $6\left(12.4 \mathrm{mg}, t_{\mathrm{R}}=15.8 \mathrm{~min}\right)$ and $3\left(1.0 \mathrm{mg}, t_{\mathrm{R}}=45.6 \mathrm{~min}\right)$ were obtained from Fr. G2d (211.2 mg). In addition, Fr. G2g (10.0 $\mathrm{mg}$ ) afforded $15\left(1.5 \mathrm{mg}, t_{\mathrm{R}}=16.7 \mathrm{~min}\right)$ and $14\left(1.8 \mathrm{mg}, t_{\mathrm{R}}=\right.$ 18.0 min) using HPLC $\left(\mathrm{MeOH}-\mathrm{CH}_{3} \mathrm{CN}-\mathrm{H}_{2} \mathrm{O}, 9: 5: 86,1.5\right.$ $\left.\mathrm{mL} \min ^{-1}\right)$.

Fr. I $(2.50 \mathrm{~g})$ was subjected to MPLC to give 22 parts $(\mathrm{a}-\mathrm{v})$ eluted with $\mathrm{MeOH}-\mathrm{H}_{2} \mathrm{O}(10 \%-100 \%)$. Fr. Ig (84.1 mg, from $30 \%$ ) was chromatographed over Sephadex LH-20 eluted with $\mathrm{MeOH}$ to obtain part $2(63.3 \mathrm{mg})$, which was further purified to afford $8\left(2.6 \mathrm{mg}, t_{\mathrm{R}}=31.7 \mathrm{~min}\right)$ by $\mathrm{HPLC}$ using $45 \% \mathrm{MeOH}-\mathrm{H}_{2} \mathrm{O}$

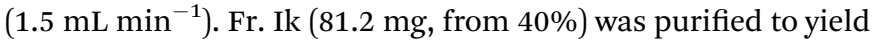
$1\left(4.6 \mathrm{mg}, t_{\mathrm{R}}=40.0 \mathrm{~min}\right), 2\left(1.2 \mathrm{mg}, t_{\mathrm{R}}=42.3 \mathrm{~min}\right)$ and 7 (20.4 $\mathrm{mg}, t_{\mathrm{R}}=48.6 \mathrm{~min}$ ) by HPLC using $47 \% \mathrm{MeOH}-\mathrm{H}_{2} \mathrm{O}(1.5$ $\left.\mathrm{mL} \min ^{-1}\right)$. Fr. Im (100.0 $\mathrm{mg}$, from $50 \%$ ) was subjected to Sephadex LH-20 eluted with $\mathrm{MeOH}$ and then purified to yield 10 (33.3 $\mathrm{mg}, t_{\mathrm{R}}=30.7 \mathrm{~min}$ ) by HPLC with $58 \% \mathrm{MeOH}-\mathrm{H}_{2} \mathrm{O}$ containing $0.1 \%$ acetic acid $\left(1.5 \mathrm{~mL} \mathrm{~min}^{-1}\right)$. Fr. It $(77.7 \mathrm{mg}$, from 70\%) afforded 11 (8.8 mg) and 12 (8.4 mg) over Sephadex LH-20 eluted with $\mathrm{MeOH}$.

Fr. L (1.90 g) was subjected to MPLC eluted with $\mathrm{MeOH}-\mathrm{H}_{2} \mathrm{O}$ (10-100\%), and Fr. La-Fr. Lm was obtained. Fr. Lc $(59.2 \mathrm{mg}$, from $45 \%)$ was purified by $\mathrm{HPLC}\left(34 \% \mathrm{MeOH}-\mathrm{H}_{2} \mathrm{O}, 1.5\right.$ $\left.\mathrm{mL} \min ^{-1}\right)$ to yield $9\left(3.2 \mathrm{mg}, t_{\mathrm{R}}=41.5 \mathrm{~min}\right)$. Fr. Lf (39.7 mg, from $70 \%)$ yielded $13\left(9.2 \mathrm{mg}, t_{\mathrm{R}}=11.2 \mathrm{~min}\right)$ using HPLC $(90 \%$ $\left.\mathrm{MeOH}-\mathrm{H}_{2} \mathrm{O}, 1.5 \mathrm{~mL} \min ^{-1}\right)$.

Ophiofuranone A (1). White solid; $[\alpha]_{20}^{\mathrm{D}}=-38.7$ (c 0.1 , $\mathrm{MeOH}) ; \mathrm{UV}(\mathrm{MeOH}) \lambda_{\max }(\log \varepsilon) 211$ (3.84), 257 (3.60) nm; ECD $(\mathrm{MeOH}): 261(\Delta \varepsilon-2.24), 306(\Delta \varepsilon+0.55) \mathrm{nm}$; IR $\nu_{\max } 3384,2986$, 2939, 1747, 1607, $911 \mathrm{~cm}^{-1} ;{ }^{1} \mathrm{H}$ and ${ }^{13} \mathrm{C}$ NMR data, see Table 1; HRESIMS: $m / z 279.1229$ for $[\mathrm{M}+\mathrm{H}]^{+}$, calcd. 279.1227 and 296.1495 for $\left[\mathrm{M}+\mathrm{NH}_{4}\right]^{+}$, calcd. 296.1492, for $\mathrm{C}_{15} \mathrm{H}_{22} \mathrm{NO}_{5}{ }^{+}$.

Ophiofuranone B (2). White solid; $[\alpha]_{20}^{\mathrm{D}}=-36.2(c \quad 0.1$, $\mathrm{MeOH})$; UV (MeOH) $\lambda_{\max }(\log \varepsilon) 221$ (3.99) nm; ECD (MeOH): $263(\Delta \varepsilon-3.46), 313(\Delta \varepsilon+0.57) \mathrm{nm}$; IR $\nu_{\max } 3429,2984,2945$, 1751, 1593, 1430, 739, $728 \mathrm{~cm}^{-1} ;{ }^{1} \mathrm{H}$ and ${ }^{13} \mathrm{C}$ NMR data, see Table 1; HRESIMS: $m / z 301.1050$ for $[\mathrm{M}+\mathrm{Na}]^{+}$, calcd. 301.1052, for $\mathrm{C}_{15} \mathrm{H}_{18} \mathrm{O}_{5} \mathrm{Na}^{+}$.

Ophiochromanone (3). White needle crystals; mp $116-117^{\circ} \mathrm{C} ;[\alpha]_{20}^{\mathrm{D}}=+35.1(c 0.1, \mathrm{MeOH}) ; \mathrm{UV}(\mathrm{MeOH}) \lambda_{\max }(\log \varepsilon)$ 223 (4.18), 260 (3.60), 335 (3.31) nm; ECD (MeOH): $222(\Delta \varepsilon$ +2.33), $317(\Delta \varepsilon-3.46), 351(\Delta \varepsilon+0.83) \mathrm{nm}$; IR $\nu_{\max } 2974,1727$, 1684, 1603, $1582 \mathrm{~cm}^{-1} ;{ }^{1} \mathrm{H}$ and ${ }^{13} \mathrm{C}$ NMR data, see Table 2; HRESIMS: $m / z 299.1261$ for $\left[\mathrm{M}+\mathrm{Na}^{+}\right.$, calcd. 299.1259, for $\mathrm{C}_{16} \mathrm{H}_{20} \mathrm{O}_{4} \mathrm{Na}^{+}$.

Ophiolactone (4). Colourless solid; $[\alpha]_{20}^{\mathrm{D}}=+14.4$ (c 0.1 , $\mathrm{MeOH}) ; \mathrm{UV}(\mathrm{MeOH}) \lambda_{\max }(\log \varepsilon) 224$ (4.07), 251 (3.57), 310 (3.18) nm; ECD (MeOH): $233(\Delta \varepsilon-0.94), 261(\Delta \varepsilon-2.15), 306(\Delta \varepsilon$ $+0.68) \mathrm{nm}$; IR $\nu_{\max } 2930,1737 \mathrm{~cm}^{-1} ;{ }^{1} \mathrm{H}$ and ${ }^{13} \mathrm{C}$ NMR data, see
Table 2; HRESIMS: $m / z 233.1170$ for $[\mathrm{M}+\mathrm{H}]^{+}$, calcd. 233.1172 for $\mathrm{C}_{14} \mathrm{H}_{17} \mathrm{O}_{3}{ }^{+}$.

Ophioisocoumarin (5). White needle crystals; mp 245$250{ }^{\circ} \mathrm{C} ;[\alpha]_{20}^{\mathrm{D}}=+196.0(c 0.1, \mathrm{MeOH}) ; \mathrm{UV}(\mathrm{MeOH}) \lambda_{\max }(\log \varepsilon) 216$ (4.23), 272 (3.99), 314 (3.74) nm; ECD (MeOH): $240(\Delta \varepsilon+10.15)$, $271(\Delta \varepsilon+11.8), 315(\Delta \varepsilon-1.72) \mathrm{nm}$; IR $\nu_{\max } 3314,1679,1642$, $1612 \mathrm{~cm}^{-1}$; ${ }^{1} \mathrm{H}$ and ${ }^{13} \mathrm{C}$ NMR data, see Table 3; HRESIMS: $\mathrm{m} / \mathrm{z}$ 221.0805 for $[\mathrm{M}+\mathrm{H}]^{+}$, calcd. 221.0814 for $\mathrm{C}_{12} \mathrm{H}_{13} \mathrm{O}_{4}{ }^{+}$.

Ophiokorrin (10). White needle crystals; mp 108-114 ${ }^{\circ} \mathrm{C}$; $[\alpha]_{20}^{\mathrm{D}}=-8.8$ (c 0.1, MeOH); UV (MeOH) $\lambda_{\max }(\log \varepsilon) 250$ (3.90); $\operatorname{ECD}(\mathrm{MeOH}): 215(\Delta \varepsilon+5.29), 240(\Delta \varepsilon-3.38), 295(\Delta \varepsilon-0.17) \mathrm{nm}$; IR $\nu_{\max } 2957,1709,1644,1582 \mathrm{~cm}^{-1} ;{ }^{1} \mathrm{H}$ and ${ }^{13} \mathrm{C}$ NMR data, see Table 3; HRESI MS: $m / z 251.1644$ for $[\mathrm{M}+\mathrm{H}]^{+}$, calcd. 251.1642 and 273.1642 for $[\mathrm{M}+\mathrm{Na}]^{+}$, calcd. 273.1641, $\mathrm{C}_{15} \mathrm{H}_{22} \mathrm{O}_{3} \mathrm{Na}^{+}$.

\section{$X$-ray single crystal diffraction}

Ophiochromanone (3) was obtained as white crystals from $\mathrm{MeOH}$ using the vapour diffusion method.

Crystal structure determination of $3 . \mathrm{C}_{16} \mathrm{H}_{20} \mathrm{O}_{4}, M_{\mathrm{r}}=276.32$, triclinic, space group $P 1, a=8.9882(3) \AA, b=9.3953(3) \AA, c=$ 10.2162(4) ̊, $\alpha=69.449(2)^{\circ}, \beta=70.162(2)^{\circ}, \gamma=66.207(2)^{\circ}, V=$ $719.21(5) \AA^{3}, Z=2, D_{\text {calcd }}=1.276 \mathrm{~g} \mathrm{~cm}^{-3}, T=296(2) \mathrm{K}, \mu(\mathrm{Cu}$ $\mathrm{K} \alpha)=1.542 \mathrm{~mm}^{-1}, F(000)=296,4090$ reflections measured $\left(4.750^{\circ} \leq 2 \theta \leq 72.230^{\circ}\right)$, independent reflections: $3526\left[R_{\mathrm{int}}=\right.$ $\left.0.1069, R_{\text {sigma }}=0.1084\right]$. The final $R_{1}$ values were $0.0603, \mathrm{w} R_{2}=$ $0.1427(I>2 \sigma(I))$. The Flack parameter value was $-0.2(4)$. CCDC number: 1855706.

Ophioisochromanone (5) was obtained as white crystals from $\mathrm{MeOH}$ using the vapour diffusion method.

Crystal structure determination of $5 . \mathrm{C}_{12} \mathrm{H}_{10} \mathrm{O}_{4}, M_{\mathrm{r}}=218.20$, orthorhombic, space group $P 22_{1} 2_{1} 2_{1}, a=5.2763(4) \AA, b=$ 13.5393(9) ̊, $c=14.7358(7) \AA, \alpha=\beta=\gamma=90^{\circ}, V=1052.69(12)$ $\AA^{3}, Z=4, D_{\text {calcd }}=1.377 \mathrm{~g} \mathrm{~cm}^{-3}, T=293(2) \mathrm{K}, \mu(\mathrm{Cu} \mathrm{K} \alpha)=1.542$ $\mathrm{mm}^{-1}, F(000)=456,3254$ reflections measured $\left(8.871^{\circ} \leq 2 \theta \leq\right.$ $\left.136.412^{\circ}\right)$, independent reflections: $1509\left[R_{\text {int }}=0.1324, R_{\text {sigma }}=\right.$ $0.1061]$. The final $R_{1}$ values were $0.0915, \mathrm{w} R_{2}=0.2209(I>2 \sigma(I))$. The Flack parameter value was 0.0(3). CCDC number: 1849055.

Ophiokorrin (9) was obtained as white crystals from $\mathrm{MeOH}$ using the vapour diffusion method.

Crystal structure determination of 9. $\mathrm{C}_{13} \mathrm{H}_{16} \mathrm{O}_{6}, M_{\mathrm{r}}=268.26$, orthorhombic, space group $P 2{ }_{1} 2_{1} 2_{1}, a=12.4892(3) \AA, b=$ 13.7293(4) ̊, $c=14.9296(4) \AA, \alpha=\beta=\gamma=90^{\circ}, V=2559.95(12)$ $\AA^{3}, Z=8, D_{\text {calcd }}=1.392 \mathrm{~g} \mathrm{~cm}^{-3}, T=293(2) \mathrm{K}, \mu(\mathrm{Cu} \mathrm{K} \alpha)=1.542$ $\mathrm{mm}^{-1}, F(000)=1136,9827$ reflections measured $\left(4.375^{\circ} \leq 2 \theta \leq\right.$ $\left.71.865^{\circ}\right)$, independent reflections: $3569\left[R_{\text {int }}=0.1538, R_{\text {sigma }}=\right.$ $0.0888]$. The final $R_{1}$ values were $0.0910, \mathrm{w} R_{2}=0.2401(I>2 \sigma(I))$. The Flack parameter value was 0.4(5). CCDC number: 1873977.

Ophiokorrin (10) was obtained as white crystals from $\mathrm{MeOH}$ using the vapour diffusion method.

Crystal structure determination of 10. $\mathrm{C}_{15} \mathrm{H}_{22} \mathrm{O}_{3}, M_{\mathrm{r}}=$ 250.32, monoclinic, space group $P 2_{1}, a=12.5559(4) \AA ̊, ~ b=$ 10.0704(3) А, $c=12.2295(4) \AA, \beta=113.522(2)^{\circ}, \alpha=\gamma=90^{\circ}, V=$ 1417.84(8) $\AA^{3}, Z=4, D_{\text {calcd }}=1.173 \mathrm{~g} \mathrm{~cm}^{-3}, T=296(2) \mathrm{K}, \mu(\mathrm{Cu}$ $\mathrm{K} \alpha)=1.542 \mathrm{~mm}^{-1}, F(000)=544,8466$ reflections measured $\left(7.679^{\circ} \leq 2 \theta \leq 136.576^{\circ}\right)$, independent reflections: $4226\left[R_{\text {int }}=\right.$ $\left.0.0856, R_{\text {sigma }}=0.0785\right]$. The final $R_{1}$ values were $0.0659, \mathrm{w} R_{2}=$ 
$0.1644(I>2 \sigma(I))$. The Flack parameter value was 0.1(2). CCDC number: 1855023.

\section{Phytotoxic effects on the root elongation of seeds of $A$. thaliana}

Seeds of $A$. thaliana were cleaned using EtOH- $\mathrm{H}_{2} \mathrm{O}(75: 25, \mathrm{v} / \mathrm{v})$ for $3 \mathrm{~min}$, followed by $100 \% \mathrm{EtOH}$ for $2 \mathrm{~min}$, and finally washed with sterilized $\mathrm{H}_{2} \mathrm{O}$ (five times) for surface sterilization. Compounds 6-8, 10 and 13 were dissolved in DMSO to a concentration of $40 \mathrm{mg} \mathrm{mL}{ }^{-1}$. Then, different volumes $(1.25$, $2.5,5,10$ and $20 \mu \mathrm{L}$ ) of each solution were added to $10 \mathrm{~mL}$ of $1 / 2$ MS medium to obtain plates with different concentrations of compounds $\left(5,10,20,40\right.$ and $\left.80 \mu \mathrm{g} \mathrm{mL}{ }^{-1}\right)$. To eliminate the effect of DMSO on the growth of $A$. thaliana, plates with the same volumes of DMSO were used as blank controls. Ten seeds were distributed on each square Petri dish $(10.0 \times 10.0 \mathrm{~cm})$ as described before. Three replicates were performed for each concentration. The seeds were placed in a growth chamber at 28 $\pm 1{ }^{\circ} \mathrm{C}$ under $12 \mathrm{~h}$ of light and $12 \mathrm{~h}$ of darkness. After ten days, the lengths of the seedling roots were measured for statistical analysis. $^{27}$

\section{Computational details}

ECD calculations were carried out as described previously. ${ }^{28}$ Conformational searches were performed by means of Frog2

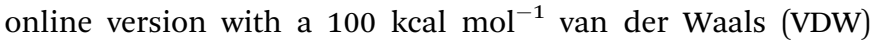
energy window from the global minimum. ${ }^{29}$ Further geometrical optimization and vibrational evaluation with the Gaussian 09 program were performed using DFT calculations [using the b3pw91 functional and the TZVP basis set]. The singlet electronic excitation energies and rotational strengths in $\mathrm{MeOH}$ were calculated by TDDFT at the mPW1PW91/6-311G(d) level of theory. The ECD curve for each conformer was simulated according to the eqn (8d) with a value of $\sigma=0.3 \mathrm{eV} .^{30}$ The final ECD spectrum was generated by summing the individual conformer values with respect to their Boltzmann statistics.

Gauge-independent atomic orbital (GIAO) calculations of ${ }^{1} \mathrm{H}$ and ${ }^{13} \mathrm{C}$ NMR chemical shifts for the optimized conformers of $(2 S, 6 S, 7 R)-\mathbf{1}$ and $(2 S, 6 R, 7 S)-\mathbf{1}$ were accomplished at the mPW1PW91-SCRF(DMSO)/6-311G(2d,p) level in the polarizable continuum solvation model. The calculated NMR data of the lowest energy conformers for $(2 S, 6 S, 7 R)-\mathbf{1}$ and $(2 S, 6 R, 7 S)$-1 were averaged according to the Boltzmann distribution theory and their relative Gibbs free energy. The ${ }^{1} \mathrm{H}$ and ${ }^{13} \mathrm{C}$ NMR chemical shifts for TMS were calculated by the same protocol and used as a reference. The experimental and calculated data were analysed by the improved probability $\mathrm{DP}^{+}$method for isomeric compounds. A significantly higher $\mathrm{DP}^{+}$probability score for $(2 S, 6 R, 7 S)-1$ suggested the correctness of its configuration.

\section{Conflicts of interest}

The authors declare no conflict of interest.

\section{Acknowledgements}

This work was financially supported by the National Natural Science Foundation of China (No. 81630093, 81874293). We thank Mr Hongbo Zheng and Ms Ke Xu for the NMR measurements. Ms Yanan Qiao and Dr Jiaozhen Zhang are also acknowledged for the X-ray diffraction analysis.

\section{References}

1 J. J. Kellogg and H. A. Raja, Phytochem. Rev., 2017, 16, 271293.

2 P. A. Paranagama, E. M. Wijeratne, A. M. Burns, M. T. Marron, M. K. Gunatilaka, A. E. Arnold and A. A. Gunatilaka, J. Nat. Prod., 2007, 70, 1700-1705.

3 B. N. Singh, D. K. Upreti, V. K. Gupta, X. F. Dai and Y. M. Jiang, Trends Biotechnol., 2017, 35, 808-813.

4 X. B. Li, L. Li, R. X. Zhu, W. Li, W. Q. Chang, L. L. Zhang, X. N. Wang, Z. T. Zhao and H. X. Lou, J. Nat. Prod., 2015, 78, 2155-2160.

5 W. Li, W. Gao, M. Zhang, Y. L. Li, L. Li, X. B. Li, W. Q. Chang, Z. T. Zhao and H. X. Lou, J. Nat. Prod., 2016, 79, 2188-2194.

6 F. Xie, W. Q. Chang, M. Zhang, Y. Li, W. Li, H. Z. Shi, S. Zheng and H. X. Lou, Sci. Rep., 2016, 6, 33687.

7 Y. H. Zhou, M. Zhang, R. X. Zhu, J. Z. Zhang, F. Xie, X. B. Li, W. Q. Chang, X. N. Wang, Z. T. Zhao and H. X. Lou, J. Nat. Prod., 2016, 79, 2149-2157.

8 F. J. Flores, S. M. Marek, G. Orquera and N. R. Walker, Crop Sci., 2017, 57, S249-S261.

9 Y. L. Li, R. X. Zhu, J. Z. Zhang, F. Xie, X. N. Wang, K. Xu, Y. N. Qiao, Z. T. Zhao and H. X. Lou, ACS Omega, 2018, 3, 176-180.

10 G. Li, H. Y. Wang, R. X. Zhu, L. M. Sun, L. N. Wang, M. Li, Y. Y. Li, Y. Q. Liu, Z. T. Zhao and H. X. Lou, J. Nat. Prod., 2012, 75, 142-147.

11 G. P. Yin, Y. R. Wu, M. H. Yang, T. X. Li, X. B. Wang, M. M. Zhou, J. L. Lei and L. Y. Kong, Org. Lett., 2017, 19, 4058-4061.

12 H. Anke, I. Casser, M. Schrage and W. Steglich, J. Antibiot., 1988, 41, 1681-1684.

13 H. Burghart-Stoll and R. Brückner, Eur. J. Org. Chem., 2012, 3978-4017.

14 N. Grimblat, M. M. Zanardi and A. M. Sarotti, J. Org. Chem., 2015, 80, 12526-12534.

15 A. M. Sarotti, Org. Biomol. Chem., 2018, 16, 944-950.

16 D. Slade, D. Ferreira and J. P. Marais, Phytochemistry, 2005, 66, 2177-2215.

17 H. Cui, M. Ding, D. Huang, Z. R. Zhang, H. T. Liu, H. B. Huang and Z. G. She, RSC Adv., 2017, 7, 20128-20134.

18 W. C. Tayone, S. Kanamaru, M. Honma, K. Tanaka, T. Nehira and M. Hashimoto, Biosci., Biotechnol., Biochem., 2011, 75, 2390-2393.

19 Y. X. Song, J. Wang, S. W. Li, B. Cheng, L. Li, B. Chen, L. Liu, Y. C. Lin and Y. C. Gu, Planta Med., 2012, 78, 172-176.

20 A. L. Gerea, K. M. Branscum, J. B. King, J. You, D. R. Powell, A. N. Miller, J. R. Spear and R. H. Cichewicz, Tetrahedron Lett., 2012, 53, 4202-4205. 
21 T. El-Elimat, H. A. Raja, M. Figueroa, J. O. Falkinham and N. H. Oberlies, Phytochemistry, 2014, 104, 114-120.

22 W. C. Tayone, M. Honma, S. Kanamaru, S. Noguchi, K. Tanaka, T. Nehira and M. Hashimoto, J. Nat. Prod., 2011, 74, 425-429.

23 P. M. Dewick, Medicinal Natural Products: A Biosynthetic Approach, John Wiley \& Sons, Ltd, 3rd edn, 2009, pp. 64-131.

24 T. Asai, K. Tsukada, S. Ise, N. Shirata, M. Hashimoto, I. Fujii, K. Gomi, K. Nakagawara, E. N. Kodama and Y. Oshima, Nat. Chem., 2015, 7, 737-743.

25 T. Oritani and H. Kiyota, Nat. Prod. Rep., 2003, 20, 414-425.
26 F. Aquea, F. Federici, C. Moscoso, A. Vega, P. Jullian, J. Haseloff and P. Arce-Johnson, Plant, Cell Environ., 2012, 35, 719-734.

27 P. H. Fan, K. Hostettmann and H. X. Lou, Chemoecology, 2010, 20, 223-227.

28 G. Li, S. Kusari, C. Golz, H. Laatsch, C. Strohmann and M. Spiteller, J. Nat. Prod., 2017, 80, 983-988.

29 M. A. Miteva, F. Guyon and P. Tuffery, Nucleic Acids Res., 2010, 38, W622-W627.

30 P. J. Stephens and N. Harada, Chirality, 2010, 22, 229-233. 